\title{
Carbenicillin Indanyl
}

National Cancer Institute

\section{Source}

National Cancer Institute. Carbenicillin Indanyl. NCI Thesaurus. Code C76219.

The indanyl ester of carbenicillin, a broad-spectrum, semisynthetic penicillin derivative with antibacterial activity. Following absorption, carbenicillin indanyl is rapidly hydrolyzed to the active carbenicillin, which binds to and inactivates penicillin-binding proteins (PBPs) located on the inner membrane of the bacterial cell wall, thereby preventing the crosslinkage of peptidoglycans, which are critical components of the bacterial cell wall. This leads to a weakening of the bacterial cell wall, eventually causing bacterial cell lysis. 